\title{
Bringing Religion Back In? \\ Debating Religion in International Politics
}

\author{
Eyüp Ersoy \\ Bilkent University
}

\section{Review article of 3 books:}

1. Andrew Phillips, War, Religion and Empire: The Transformation of International Orders (Cambridge: Cambridge University Press, 2011, xii + 364 pp., USD 82.68, hardcover).

2. Timothy Samuel Shah, Alfred Stepan, Monica Duffy Toft, eds., Rethinking Religion and World Affairs (Oxford: Oxford University Press, 2012, x + 319 pp., USD 29.95, paper.).

3. Timothy Fitzgerald, Religion and Politics in International Relations: The Modern Myth (London: Continuum, 2011, x +284 pp., USD 39.85, paper.).

Observing the shattering of the European society's axiological foundations and traditional systems of meaning, which had been constituted and sustained by and through Christianity, under the rampant secularism of his time, Nietzsche has a madman declare the death of God in The Gay Science: "God is dead. God remains dead. And we have killed him"." His observation was also valid for the international politics of the time, in which secular ideologies had long replaced religion as the ideational aspect of international politics. The competition among these new ideologies, after contributing in varying degrees to several upheavals in international politics, arguably ended with the collapse of the Soviet Union with socialism as its avowed ideology, leaving liberalism as the lone secular ideology with the United States as its avowed political custodian. ${ }^{2}$

Nonetheless, after the end of the Cold War, religious convictions, actors, practices, and institutions have become more visible in the practice of international relations, and yet, for different reasons, the study of the increasing role of religion and the religious in international affairs has been elided. ${ }^{3}$ One reason for this disciplinary inertia pertains to the praxis of international relations. It is an unfortunate conjunction that this field's formative period after World War I coincided with World War II and the Cold War, which placed an overwhelming imperative on the study of 'high politics' to the exclusion of issues of 'low politics'. Nonetheless, after the end of the Cold War ideational aspects of international relations once overlooked as 'low politics' or 'below politics' have become more visible in the scholarly study of international relations.

The fundamental reason for the omission, however, is the discipline's secular nature, which has been a categorical impediment to including religion and has been highlighted

\footnotetext{
Eyüp Ersoy, PhD Candidate, Department of International Relations, Bilkent University; Research Assistant, Department of International Relations, Y1ldırım Beyazıt University. E-mail: eersoy@bilkent.edu.tr

Friedrich Nietzsche, trans. Walter Kaufmann, The Gay Science (New York: Vintage Books, 1974), 181.

For the role of ideologies in current international relations, see Alan Cassels, Ideology and International Relations in the Modern World (London: Routledge, 1996).

3 Here, 'religion' denotes a general system of belief with a dimension of extratemporal immanence and/or transcendence, while 'religious' denotes actors and practices related to religion.
} 
by several scholars. ${ }^{4}$ Edward Luttwak, for example, argued in the immediate aftermath of the Cold War that "astonishingly persistent, Enlightenment prejudice has remained amply manifest in the contemporary professional analysis of foreign affairs". ${ }^{5}$ According to Luttwak, "policymakers, diplomats, journalists and scholars... are still in the habit of disregarding the role of religion, religious institutions, and religious motivations in explaining politics and conflict..." and, as a result of this prejudiced scholarly attitude, "one is therefore confronted with learned repugnance to contend intellectually with all that is religion or belongs to it". ${ }^{6}$

Acknowledging the increasing relevancy of religion in the practice of international affairs especially after $9 / 11$, a growing number of scholars have ventured to explore the intricate relationships between religion and international relations. ${ }^{7}$ Although the majority of studies is devoted to examining the relationship between violence and religion, especially Islam, comprehensive accounts discussing the place and role of religion in international relations have also appeared. Pavlos Hatzopoulos and Fabio Petito's edited volume Religion and International Relations: The Return from Exile is an important post-9/11 contribution to the literature, and the editors, who are of the conviction that "the rejection of religion...seems to be inscribed in the genetic code of the discipline of IR", 8 contend that "having unexpectedly survived the long Westphalian exile, religion is back to the center of international relations". 9 The contributors, including John L. Esposito, Richard Falk, and Ole Waever, among others, debate the interplay between religion and international affairs from a multitude of perspectives. ${ }^{10}$

Nevertheless, until now, the existing literature exhibited some shortcomings. The first was the lack of historical and systemic treatment of religion in international relations. The second was an overemphasis on the study of violence and religion in international relations. The third was the lack of semantic consciousness and conceptual self-reflection in the discussions of the issue. Three recently published works further explore the debate, analyzing it from different yet complementary perspectives. Andrew Phillips examines the role of the religious and the political in constituting and transforming international orders in his comparative historical study, and thus engages in a system-level analysis of the place of religion in international politics. ${ }^{11}$ Timothy Samuel Shah, Alfred Stepan, and Monica Duffy Toft's edited volume is more general in scope, and deals with multiple issues concerning religion and contemporary international relations, including secularism and secularization, democracy and human rights, conflict and peacemaking, humanitarianism and civil society, media, and American

4 For example, Timothy Samuel Shah and Daniel Philpott, "The Fall and Rise of Religion in International Relations: History and Theory," in Religion and International Relations Theory, ed. Jack Snyder (New York: Columbia University Press, 2011), 24-59; Elizabeth Shakman Hurd, "Secularism and International Relations Theory," in Religion and International Relations Theory, ed. Jack Snyder (New York: Columbia University Press, 2011), 60-90.

Edward Luttwak, "The Missing Dimension," in Religion, the Missing Dimension of Statecraft, eds. Douglas Johnston and Cynthia Sampson (New York: Oxford University Press, 1994), 9.

6 Luttwak, "Missing," 9-10.

7 In this review article, 'international relations' and 'international affairs' are used interchangeably, while 'international politics' is distinguished from them, and is used to denote the political facet or form of international relations/affairs.

8 Pavlos Hatzopoulos and Fabio Petito, "The Return from Exile: An Introduction," in Religion in International Relations: The Return from Exile, eds. Pavlos Hatzopoulos and Fabio Petito (New York: Palgrave Macmillan, 2003 ), 1.

9 Hatzopoulos and Petito, "An Introduction," 2.

10 For another contribution forcefully calling for the incorporation of religion in the study, and especially theory, of international relations, see Scott M. Thomas, The Global Resurgence of Religion and the Transformation of International Relations (New York: Palgrave Macmillan, 2005).

11 Andrew Phillips, War, Religion and Empire: The Transformation of International Orders (Cambridge: Cambridge University Press, 2011). The title is abbreviated as WRE within this text. 
foreign policy. ${ }^{12}$ Timothy Fitzgerald questions the generic employment of the categories of religion and politics, and undertakes a critical deconstruction of these categories as employed in other works of the literature. ${ }^{13}$ In this article, I discuss the contributions of these scholars to the debate on the role and place of religion in international relations. First, I introduce their arguments then critically appraise the strengths and shortcomings of their analyses. Last, I discuss their insights in reference to my main argument.

It is my contention that religion and the religious is relevant to the practice and study of international relations, and yet the extent of its relevancy is, and will be, determined by the extent of troubled interactions between the religious and the political, especially the liberal, in contemporary international relations. This argument is predicated upon two premises. First, religion and politics are distinct realms of social existence and activity, and are based on different systems of meaning and value. Second, religion and politics are both authoritative institutions, in the sense that they are both sources of authority which makes both the religious and the political to become proprietors and enforcers of authority. Although ontologically separate sources of authority, religion and politics address the same audience as the subject of their authority in which the authority claims of religion and politics interact. In some cases, the interaction is symbiotic, but in all cases it is hierarchical, that is, one side's authority always takes priority over the other's. Therefore, I argue, a balanced relationship between the religious and the political in international relations is not likely, and in cases of active engagements with each other, the relationship is always asymmetrical.

\section{Religion and International Dis/orders}

In WRE, Andrew Phillips examines the role of religion in conjunction with war in the constitution, continuation, and collapse of international orders from a long-term historical perspective. Phillips' theoretical and empirical examination involves a comparative case study of Latin Christendom, the Sinosphere, and the global state system. ${ }^{14}$ Three research questions underpin Phillips' account: 1) the nature of international orders, 2) the causes and the process of their transformations, and 3) the ways that were historically employed in Latin Christendom and the Sinosphere, and are currently employed in the global state system to counter challenges to their integrity. On the nature of international orders, Phillips advances a theoretically eclectic argument consisting of two parts. First, concentrating on "the order-producing norms and institutions that define international orders", he affirms that "international orders depend on the existence of an order-enabling material context" (5). Second, he maintains that international orders are teleological in nature and intrinsically dualistic in their formation. On the one hand, "international orders seek to advance a normatively thick and culturally and historically contingent vision of the good", while on the other hand, "international orders are also dedicated to the more basic objective of containing violent conflict between different polities within manageable bounds" (5).

In an elaborate analysis, Phillips defines international orders as composed of three constitutive elements: a normative complex, fundamental institutions, and a material context. A normative complex provides "actors with the "maps of meaning necessary to navigate social

12 Timothy Samuel Shah, Alfred Stepan, and Monica Duffy Toft, eds., Rethinking Religion and World Affairs (New York: Oxford University Press, 2012). The title is abbreviated as RRWA within this text.

13 Timothy Fitzgerald, Religion and Politics in International Relations: The Modern Myth (London: Continuum, 2011). The title is abbreviated as RPIR within this text.

14 References to WRE are included in the text in parentheses. 
life, conferring upon them a shared collective identity, as well as a common ethical system and a framework for recognising and legitimising political authority" (24). "Authoritative institutions that wield supreme authority within a given issue area and/or territory", "a legal or ritual framework that codifies agents' rights and obligations", and "authorised practices of legitimate violence through which order is enforced, violators are punished, and injuries are remedied" constitute the fundamental institutions of an international order (26-27). Finally, an international order's normative complex and fundamental institutions are embedded within a material context. "Aggregate social capacities for organized production and destruction", "the configuration of mobilizational networks", and "the volume and density of interactions" constitute the three most prominent characteristics of material context (29).

Phillips' emphasis on the dualistic nature of international orders is also evident in his argument about their continuation. To Phillips, a combination of authoritative institutions and coercive institutions sustains international orders. While authoritative institutions "attract agents' compliance through their concordance with shared standards of legitimacy", coercive institutions 'compel agents' compliance through the application of authorised practices of organized violence" (6). In the most general terms, international orders transform when "the organising principle that governs relations of authority between different political communities" constituting an international order changes along with "its constitutional values and fundamental institutions" (6-7).

According to Phillips, the collapse of international orders is a result of ideational and material changes. Ideationally, "it entails the emergence of anti-systemic ideologies that explicitly contest either part or all of the normative complex underpinning the existing international order" (8). Phillips calls this situation an ideological schism, and it subverts an international order in two ways. First, it destroys "the normative consensus necessary to sustain the operation of fundamental institutions, effectively paralysing collective capacities to manage and contain violent conflict", and second, it polarizes "polities both internally and internationally between defenders and opponents of the existing order" (8). Materially, "technologically driven increases in the scale of and scope of violent international conflict" compounds ideational challenges to an international order (9). It can easily be seen that the causal primacy in Phillips' account is accorded to ideational factors, notwithstanding the incorporation of material factors.

For Phillips, the demise of Latin Christendom is attributable first to the advent of a religious movement, the Reformation, which challenged the normative complex and fundamental institutions of the established international order sustained by the Catholic Church and imperial arrangements, and subsequently caused a severe legitimacy crisis within the order, culminating in the Thirty Years' War. The second factor in its demise was the introduction of more destructive military and technological capacities, enabled by the increasing wealth created by incipient commercialization, which destroyed the existing order-enabling material context and ushered in a new international order (59-148). In the same vein, the collapse of the Sinosphere was the result of a combination of the ideational and material decay of the Qing dynasty, internal rebellions (the gravest being the Taiping Rebellion), and the increasing rapacity of, first, Western powers, and then Japan (149-258). In the case of the global state system, Phillips discusses the current situation and the future of the contemporary world order against the challenge of radical Islamism, specifically, "the 
most extreme anti-systemic expression of radical Islamism, namely the transnational Salafijihadist terrorist threat embodied in Al Qaeda and its many offshoots" (263).

Before discussing the place of religion and the religious in Phillips' account of the transformation of international relations and the insights that can be drawn from the relationships between the religious and the political, a critical appraisal of the basic strengths and weaknesses of his analysis is needed. Its strength, which is also its substantial contribution, is its holistic approach, which incorporates normative, institutional, and material factors to account for the transformation of international orders in an attempt to transcend the realist/ constructivist and materialist/idealist dualisms in international relations scholarship. On the other hand, there is also a serious shortcoming in his analysis. Despite their seeming similarities, the nature of the transformations in Latin Christendom and the Sinosphere are empirically distinct, and thus the two cases are incomparable causing a problem of incommensurability.

The transformation of the international order in Latin Christendom was endogenic, that is, intra-systemic, while the transformation of the international order in the Sinosphere was mainly exogenic, that is, inter-systemic. Starting with the Opium Wars, and continuing till the defeat of Japan by the US in World War II, the transformation of the Sinosphere was conditioned, and more often than not forcefully affected, by the policies of external actors, a phenomenon empirically identified by Phillips himself (for example, 174-182). While intrasystemic transformation of Latin Christendom ushered in another international order within the same system, the Sinosphere was liquidated after World War II, and incorporated into the emerging international order. Finally, the crisis of Latin Christendom's normative complex was again endogenic and exclusively ideational in character, that is, caused by an intrasystemic normative rival to the Catholic Church that challenged its legitimacy on ideational grounds. However, the crisis of the Sinosphere's normative complex was mainly exogenic, and to a great extent materially conditioned, that is, caused by inter-systemic rivals to the Heavenly Kingdom that challenged and damaged its legitimacy on ideational and material grounds. As again noted by Phillips in his account of the fall of the Sinosphere (for example, 198-214), the decay of its normative complex was intimately intertwined with changes in its material context, mainly imposed by external interventions. In other words, the successive defeats of Qing armies by foreign invaders, including Western powers and Japan, paved the way for insidious criticism, and subsequently severe debilitation, of the legitimacy of the Heavenly Kingdom and the Sinosphere, which were the fundamental causes behind its internal rebellions and associated domestic troubles. For the above reasons, then, the cases examined in Phillips' analysis accounting for the transformation of international orders are incomparable because Latin Christendom and the Sinosphere followed peculiar paths in their transformations.

Nonetheless, with regard to the role and place of religion and the religious in the transformation of international orders, Phillips' long-term historical comparative investigation is highly informative and illuminating. Religion in Latin Christendom and the Sinosphere, Catholicism and Confucianism respectively, constituted the fundamental structures over which coherent normative complexes could be built and sustained. ${ }^{15}$ Phillips disaggregates

15 It ought to be noted that it is problematic to situate Catholicism and Confucianism under the category of 'religion'; 'religious belief systems' would be a more accurate specification. This is an important point, discussed by Phillips only in passing (154); still, I use the same categorization for convenience. 
normative complex into "a composite of overlapping norms that perform identity-constitutive, ethical prescriptive and power-legitimating functions" (25). In Latin Christendom and the Sinosphere alike, religion constituted the base upon which to confer the communities and polities of the international order a collective shared identity, enabling them to relate to each other and to the world in consensual, meaningful, interpretative frameworks $(61-70,149$ 163). In addition, religion was the ultimate regulatory source; it provided norms of appropriate behavior in a given international order as well as the criteria to judge that behavior. Finally, and in a more authoritative manner, religion functioned "to convince agents that political obedience is both necessary and consistent with the demands of morality", and consolidated "established structures of domination by situating them as necessary expressions of politically salient collective identities" (26). In the Sinosphere, for example, Confucianism "worked to sustain a hierarchical order with an omnicompetent universal emperor at its pinnacle", who was construed and conceived as the Son of Heaven and who "presided over a social order conceived in organic and rigidly hierarchical terms" (155).

That religion and the religious were not without challenges, which could emerge from within and from outside, and that competition and conflict between the established religion and revisionist challengers was quite decisive in the transformation of international orders, is another important insight in Phillips' account. In Latin Christendom, the challenge emerged from within; the Reformation originated in the ideas and acts of a Christian monk, Martin Luther, and signified the onset of the collapse of the existing order. For example, in assaulting the Catholic tenet that "salvation was possible only through the Church...Luther assaulted the most basic power-legitimating norms underpinning Christendom" (87). In the Sinosphere, on the other hand, the challenge came from outside. Confucianism's terminal legitimacy crises began as an adversarial worldview of 'barbarians' (Christianity) into the social imaginary of the Sinosphere after the opening of Chinese politics, economy, and society to Western encroachment in the Opium Wars (174-193). The Taiping Rebellion of the evangelical Protestant native Chinese was as equally a theological rebellion against Confucianism as it was a political revolt against dynastic authority (182-193). Confucianism was further debilitated and finally outcast by secular ideologies originating from the West. Nationalism, republicanism, and later, socialism, challenged and delegitimized Confucianism, and by expelling it from the normative complex of the Sinosphere, these secular ideologies contributed to the collapse of that order.

Phillips' account conspicuously demonstrates that the place of religion, be it established or revisionist, in a given international order is re/negotiated in and through its relations with the political. Further, the role of religion (again, established or revisionist) in the transformation of international orders is determined by its interactions with the political. The decisive dynamic in the transformation of international orders is the nature of relationships between the religious and the political. In the constitution and continuation of Latin Christendom a concord existed between the religious and the political, wherein the religious was the dominant party in specifying the terms of the relationship. As Phillips states, "Church doctrine proclaimed that both Church and empire were divinely ordained institutions fulfilling distinct but complementary functions" (66). The Church, as the religious authority, "was responsible for assuring humanity's submission to Christ and securing the salvation of souls" and the empire, as the political authority, "was charged with securing the temporal order necessary for the Church to realize its divinely ordained mission" (66). 
However, the relationship became troubled when the political gained ascendancy. As an example, "under the pontificate of Clement VII, the papacy proved intransigent in its resistance to imperial calls for a General Council to reform the Church", whereby, to Phillips, the Church confounded the progress towards religious reconciliation "until the gap between Catholics and Protestants had become unbridgeable" (103). Protestantism, on the other hand, the revisionist religion, forged its own relationships with the political, including the Habsburg monarchy and the polities contesting the Habsburg hegemony in this particular international order. In short, the transformation of Latin Christendom involved the interplay of two religious and two political authorities in crosscutting relationships. The two religious authorities were the Church and Protestantism, and the two political authorities were the "Counter-Reformation axis" headed by the Habsburgs and "an eclectic coalition united by little more than their opposition to Habsburg power" (129).

In the Sinosphere, a similar concord existed between politics and religion in its initial constitution and subsequent continuation (150-163). However, contrary to the Church, Confucianism's religious authority was inextricably tied to the political authority of the Qing emperor; there was no institutional embodiment of Confucianism similar to the Church, and accordingly the diarchy of authorities as seen in Latin Christendom was not present in the Sinosphere. Therefore, the transformation of the Sinosphere necessarily followed a different path than Latin Christendom. Confucianism and the Qing dynasty struggled for their common survival against a multitude of foreign ideologies and predatory powers, and the weakening of one inevitably led to the weakening of the other (196-225). In the case of the Sinosphere, the religious and political authorities shared a common destiny, and a common defeat against several external religious and political challengers.

Phillips' account also follows the gradual secularization of politics and the political, and the associated descent and final expulsion of religion and the religious in the constitution and continuation of international orders. With the effective end of Latin Christendom by the Peace of Westphalia, a long-term "transition from the medieval universalism of the Respublica Christiana to the sovereign anarchy of the modern state system" (136) took hold in conjunction with "an important shift towards the secularization of [the] European order" (144). ${ }^{16}$ Religion no longer constituted the sole and ultimate normative complex, nor ideational foundation, of the national and international order in the European system, and was to be increasingly disputed and marginalized by alternative secular social imaginaries, primarily emanating from the Enlightenment. The religious also lost its authority in shaping that order's foundational institutions and material contexts.

In the Sinosphere, mainly due to inter-systemic external factors, religion in the form of Confucianism experienced the same destiny. Confucianism was discredited as the ideational foundation of the national and international order, and along with the fall of the Qing Empire, was superseded by new secular social imaginaries of Western origin. Religion's nexus with politics was severed, and the Sinosphere was liquidated through the forceful integration of the regional system into the global state system. Phillips stresses that "unlike either Christendom or the Sinosphere, the global state system lacks overt cosmological foundations" (263). However, this does not mean that it lacks ideational foundations; "the global state system

16 Phillips discusses arguments about transition to sovereign and secular Westphalian state system in detail, and after presenting a full overview of the revisionist scholarship contesting both arguments, he seems to concede the validity of them both in the final analysis (136-148). 
powerfully reflects Enlightenment legacies in its constitutional norms, with the goals of human emancipation and material progress in the temporal world entirely replacing religious imperatives as the basis for international order" (263). The current international order, however, is underpinned ideationally by the most resilient and pervasive ideological legitimacy of the Enlightenment, which is liberalism. Global state system is at the same time a liberal international order. In other words, in the contemporary international order, politics is secular, and defined exclusively by liberalism. Therefore, in the current international order, the role and place of religion and the religious are, and will be, determined by their interactions with politics and the political, especially the liberal underpinning the political. ${ }^{17}$ In order to clarify this point, it is necessary to identify the role and place of religion and the religious in contemporary international affairs in which early signs of a renegotiation of the role and place of religion with politics are discernible.

\section{Religion and Contemporary International Affairs}

Religious convictions, actors, practices, and institutions have become more visible in many areas of contemporary international affairs and have come under increasing scrutiny by scholars of varying disciplines and persuasions. In an attempt to give a comprehensive account of the interconnection of religion with several aspects of current global affairs, Timothy Samuel Shah, Alfred Stepan, and Monica Duffy Toft's edited volume deals with issues including secularism and secularization, democracy and human rights, conflict and peacemaking, humanitarianism and civil society, media, and American foreign policy. ${ }^{18}$ The rationale behind this scholarly venture is explained in its introductory chapter by the proposition that "religion has become one of the most influential factors in world affairs in the last generation but remains one of the least examined factors in the professional study and practice of world affairs" (3).

The first section pertains to the relationship between religion, secularism, and secularization in the practice and study of international affairs. J. Bryan Heir questions the absence of thoughtful consideration of the role and place of religion in international politics and advances three explanations for it. First, the Westphalian order that emerged in Europe and extended to the world in its entirety "produced a conception of international order that was sovereign and secular in character, committed to a conception of state interests as the best guide to understanding international relations" (16). Second, common to the international relations scholarship and the practice of diplomacy is pervasive diffidence and skepticism about religion and all things religious. Third, democracy entails a normative prescription that religion is, and should be, a private reality, which "undergirds the idea that religion need not be addressed in understanding the public nature of world politics" (18).

Jose Casanova contends that the three subtheses of the theory of secularization (secular institutional differentiation, decline in religious observance, and privatization of religion), have become questionable, if not invalidated, in the current state of national and international affairs, wherein 'public religions' have become more salient (25-27). Specifically in international affairs, Casanova calls attention to "the proliferation of deterritorialized

17 The debate over the inclusion of a reference to Christianity in the Treaty of Lisbon in the European Union is supportive of this argument, and exemplary of how a religious body, i.e., the Pope, attempted to find a role and place for religion in the secular politics of an emerging regional order and how this attempt was opposed and thwarted by liberal circles.

18 References to $R R W A$ are included in the text in parentheses. 
transnational global imagined communities", which, to him, "present fundamental challenges to international relations theories that are still functioning within the premises of a Westphalian international system" (33). Finally in this section, Elizabeth Shakman Hurd debates the politics of secularism in national and international affairs, critically comparing what she calls "two ideal types of secularism" (37), namely laicism and Judeo-Christian secularism, and, concurring with the previous authors, argues that "most realist and liberal approaches to international relations operate on the laicist assumption that religion has been confined to the private sphere or has disappeared" (38).

The second section of $R R W A$ discusses the relationship between religion, democracy, and human rights. Stepan presents a strong case for what he calls "twin tolerations" in public life, where there must be "minimal boundaries of freedom of action...crafted for political institutions vis-à-vis religious authorities, and for religious individuals and groups vis-à-vis political institutions" (55). He maintains that in practice many seemingly secular European states, including Denmark, Finland, Greece, Sweden, England, and Germany, are not strictly secular, and gives examples of twin tolerations. Rajev Bhargava proposes an alternative model of secularism based on India's experience in dealing with religion in public and political life. He contends that the American model of secularism (with its prominent characteristics of mutual exclusion of religion and state and passive respect for religion by state) and the French model of secularism (with its prominent characteristics of one-sided exclusion of religion from state, and active disrespect for religion by state) "have persistent difficulties coping with community oriented religions that demand greater public presence" (75). To Bhargava, the Indian model of secularism, with its prominent characteristics of principled distance and contextual secularism, is a better alternative.

Rethinking Islam and democracy, Robert W. Hefner is of the conviction that the future of democracy in contemporary Muslim states is to be determined by the debates, and especially by the positions of Muslim religious authorities on those debates, about the status of women, non-Muslims, and Muslim nonconformists in Muslim societies (89-97). Finally in this section, John Witte, Jr. and M. Christian Green discuss religion and international human rights. They specify three controversial subjects challenging the universality of the international religious freedom regime: proselytism/evangelization, conversion and apostasy, and blasphemy and religious defamation (110-117).

The third section is an examination of the role of religion in conflict and peacemaking. According to Toft, religions in general "share two key aspects relevant to the likelihood that conflict between competing groups may escalate into violence" (133). First, "religion tends to be uncompromising", and second, "religion encourages followers to discount their physical survival" (133-134). Although Toft finds an increase in the proportion of civil wars "with religion as a feature of the fight" (136), her sampling is methodologically flawed, and thus her findings are not tenable. Daniel Philpott investigates the role of religion in the realization of transitional justice based on reconciliation. Philpott denounces the liberal human rights paradigm with regards to the realization of transitional justice, maintaining that its core commitment is the punishment of perpetrators and vindication of victims (150). He finally states that religious actors have become influential in the realization of transitional justice in some cases, for they have espoused a political theology of reconciliation and have been autonomous from their states during periods of conflict and periods of transition (153157). 
In its fourth section, $R R W A$ probes the relationships between religion, humanitarianism, and civil society. Reflecting on his scholarly experiences in the field of humanitarianism, Michael Barnett observes that "in general, because they confront the same environment and respond in fairly similar ways, secular and faith-based agencies are growing more alike all the time" (166). Notwithstanding the incremental similarities in practice, in motive, religious convictions influence faith-based charitable and philanthropic action through encouraging "greater stoicism", shaping "the boundaries of the moral community", and shaping the faithbased humanitarian organization's "understanding of the social purpose of humanitarian action" (170-171). Katherine Marshall explores the issue of faith and gender in international affairs, and argues that "gender has become the preeminently contested social question, with religion thrown, willingly or unwillingly, into the vortex of the global contestation" (189).

In the subsequent chapter, Marshall turns to the issue of religion and development, and discusses the ideational and institutional setbacks inhibiting a thorough examination of religion's possible contributions to international development. In terms of development, Marshall thinks that religion is treated in civil society in the fashion of "out of sight and out of mind" (198), is seen by development technocrats as divisive (200), and is regarded in development circles as "part of the problem and part of the solution" (202). These claims call for a serious examination of the subject of religion and development. Finally in this section, Thomas Banchoff explains the ways interreligious dialogue and international relations shape each other, and contends that the dialectical relationship between the two is asymmetrical because "as in earlier eras, the course of international relations and world politics has constrained the scope and content of interreligious dialogue" (211).

The fifth section is pertinent to the uneasy relationships between religion and media. Mehrzad Boroujerdi and Nichole J. Allem investigate the effects of new media on the international and intra-national relations of the Muslim world. They seem to be of the opinion that "the omnipresence and incessancy of new media" (218) may not be a welcome development in terms of the destabilizing effects of religion on international and intranational relations of the Muslim world due to, for example, "the diminution of the power of experts, the fracturing of religious discourse, [and] the questionings of religious orthodoxies" (218). Diane Winston demonstrates how international media brought widespread protests of Buddhist monks in Burma/Myanmar against the military junta in 2007 to the attention of an international audience, and how this domestically and internationally influenced the developments concerning the turmoil there.

The sixth and last section of $R R W A$ is devoted to a discussion of religion and American foreign policy. Walter Russell Mead traces the historical trajectory of the demographics of Protestantism in the US, identifies its three most important strands as fundamentalist, liberal, and evangelical Protestant Christianity, and illustrates how shifting demographics and the power of those strands have corresponding effects on US foreign policy. Mead states that humanitarianism and human rights policies and the question of Israel occupy the highest place on the foreign policy agenda of the evangelicals, which has become the most influential Protestant strand in the US. Thomas F. Farr attributes the problems in the origins, implementation, and institutionalization of the US' International Religious Freedom Act (1998) mainly to "a deeper pathology in the American diplomatic establishment: a secularist conviction about how the world ought to work" (273). In the last, mainly prescriptive, chapter, Frederick D. Barton, Shannon Hayden, and Karin von Hippel specify some critical 
steps for improving the US government's engagement with religion in its foreign policy, especially in conflict zones, including enhancing training and exercises, regular meetings of an interagency task force, improving connectivity between civilian and military personnel, conducting regular surveys in countries where US troops are stationed, and employing new tools and partners.

The paramount contribution of this collective study, in addition to the highly insightful contributions of particular authors, is to demonstrate the irrefutable relevancy of religion to contemporary international affairs. Religion and the religious are ubiquitous in international affairs; in the forms of inspirational individuals, committed movements, and lively organizations, religion and the religious engage national and international policies, affect national and international developments, and in the process are affected by them. However, despite the general empathetic treatment of religion and the religious in the study as a potential contributor to developments in international affairs, "the ambivalence of the sacred" is also discernible. ${ }^{19}$ Religion and the religious can be promoters of peace as well as instigators of conflict, and can be sources of welfare as well as warfare. Nonetheless, drawing on the book, it can be forcefully argued that the main issues of contemporary international affairs cannot be exhaustively debated, the main developments cannot be thoroughly understood, and the main problems cannot be satisfactorily settled without including religion and the religious in its study, and without incorporating religion and the religious into its practice. On the other hand, a basic limitation of this volume in illuminating the interactions of religion and the religious with several areas and aspects of international affairs is the lack of an overarching framework and underlying argument linking otherwise highly elaborate essays to each other.

It is clearly demonstrated in my brief account of the critical points and main arguments of respective scholars in $R R W A$ that religion and the religious are relevant to international affairs. However, their relevancy to international politics, which is the political form and aspect of international affairs, is another issue..$^{20}$ To repeat my main argument, I argue that the extent of the relevancy of religion and the religious in the practice of international relations is, and will be, determined by the extent of troubled interactions between the religious and the secular political, especially the liberal, in contemporary international relations.

In the first section of $R R W A$, for example, the authors call attention to the perverse and persistent secularism of contemporary international politics, and argue that for religion and the religious to secure a credible role and place in international relations, the secularist character of international politics must be addressed and challenged. Heir indicates that although "the secular character of the modern era was taken for granted in the study and practice of world politics", secularism, "the assertion of a political order (within states and among them) that stood beyond the range of religious authority, control, or even influence, was a purposeful result of Westphalia" (17), constituting the foundation of contemporary international politics. Hurd on the other hand, identifies unarticulated presuppositions of the secular international politics, which regard "secularization as a commendable side effect of democratization and modernization" (45) and "secularization as the result of the globalization of a modern state system in which religion has been privatized once and for all" (46). However, Hurd rightly insists that "secularisms are not fixed in stone and [are] produced and renegotiated through

19 See R. Scott Appleby, The Ambivalence of the Sacred: Religion, Violence, and Reconciliation (Lanham: Rowman and Littlefield, 1999).

20 To repeat, I use 'international relations' and 'international affairs' interchangeably. 
laws, practices, and social relations, including international relations" (46). Accordingly, the increasing relevancy of religion and the religious in international relations, manifesting in the functioning of religious convictions, actors, practices, and institutions in numerous areas, is to cause troubled processes of renegotiation of religion and the religious with secular politics.

The relevancy of religion and the religious in international relations is contrary to a foundational character of current international politics, and, to repeat, the endeavor of religion and the religious to find and secure a credible role and place in international relations is certain to cause a troubled engagement with secular politics and the secular political. I further argue that liberalism is the universally dominant, and, one may add, hegemonic, secular ideology defining contemporary international politics, and thus the troubled engagement of religion and the religious with secular politics in the current era is, and will be, between the religion and the religious and liberalism and the liberal. Witte and Green's discussion of the transformation of "the international law framework of religion and human rights" (108) is indicative of this point. The debate over the inclusion of resolutions against defamation of religions in the policies of international organizations, most importantly the $\mathrm{UN}$, demonstrates the tension that emerges when religion and the religious intend to become more relevant, in this case legally, to international politics, and face the strong opposition of liberalism and the liberal (113-117).

A similar troubled engagement can be seen in the politics of transitional justice, discussed in detail by Philpott. Liberalism and the liberal have categorically opposed the arguments of religion and the religious about transitional justice. For example, "leading intellectuals in the liberal human rights school have called into question core features of religious arguments for reconciliation", through arguing, for example, that "abrogating punishment... is always a sacrifice of justice, [and] ought never to be reenvisioned as justice" (150). They additionally insist that "goals of religious reconciliation like healing, overcoming enmity, and forgiveness...violate individual autonomy, disrespect liberalism's plurality of values, and undermine central democratic virtues of argument and deliberation" (150). In short, even though religion and the religious have been instrumental in the realization of transitional justice in several cases in international affairs (153-157), their relevancy to international politics, in this case through finding a place in customary international law, let alone codified international law, is resolutely opposed by liberalism and the liberal.

Yet another example is Farr's account of the problems in the origins, implementation, and institutionalization of the US' International Religious Freedom Act (1998). The US State Department strongly opposed the bill's legislation, and when it passed in Congress, the State Department circumvented its implementation, "fear[ing] that a separate office devoted to religious issues would expose U.S. diplomacy to what they saw as the divisiveness of the Christian right, especially its goals of conversion and employing religion-based arguments in the public sphere" (270). The State Department also charged that "IRF legislation would construct an "artificial hierarchy of human rights" in foreign policy, privileging religious freedom over other equally important or more important rights" (270). The first contention of the State Department exhibits its secular character, while the second one exhibits its liberal character. In sum, the endeavor of religion and the religious to find and secure a credible role and place in US foreign policy involved a troubled engagement and renegotiation with politics and the political, in this case mainly the US State Department, which opposed 
religion and the religious becoming more relevant to the practice and institutionalization of US foreign policy on secular, and mainly liberal, grounds.

It should be noted that extensive employment of concepts like religion, the religious, politics, the political, the secular and the liberal in arguments pertinent to the role and place of religion in international politics calls for an informed consideration of the style and the substance of these concepts because the validity of the arguments depends on the validity of the concepts.

\section{Religion and Politics in International Relations: Categorical Debates}

Timothy Fitzgerald questions the generic employment of the categories of religion and politics in the debate on the role and place of religion in international relations, and undertakes a critical analysis of these categories from an epistemological/ontological perspective. ${ }^{21}$ Fitzgerald first focuses on religion, and states that despite religions being "[just the] classifications designed to indicate a distinct kind of institution, experience, or practice" (1-2), they are "spoken of, written about, described, analyzed and compared as though they are phenomena that can be observed" (2, emphasis in original). To Fitzgerald, it is an "illusion, often made theoretically explicit, that religions exist in the world as distinct kinds of things" (4).

Second, Fitzgerald holds that "the critique of the category of 'religion' leads us inevitably into a critique of all those categories deemed to represent the "non-religious' secular" (4). He contends that "there could be no secular 'politics'...without 'religion", for "the two categories are parasitic to each other", and accordingly, imagining "the non-religious secular domains such as 'politics' without the category religion operating as its binary other" is not possible (4). To Fitzgerald, this understanding of international relations constitutes "the discursive basis of a dominant modern myth that, by inventing generic religion as one side of a fantastic binary, simultaneously invents the secular as the domain of common sense and natural reason" (94).

Third, Fitzgerald insists that inventing these categories and naturalizing them through binary oppositions and unquestioned employment in discourse lead to what he calls linguistic colonialism, or hegemony. To Fitzgerald, even though categories like religion and politics are "widely used as though their meanings are distinct, obvious, and certain" (59-60), the lines dividing them are "arbitrary, provisional and contested" (60). These categories "are not obvious and transparent terms for universal realities that correspond with empirical observation, but are contested Anglophone or more widely Europhone categories with ideological work to do" (60). Displaying commendable reflexive scholarship, Fitzgerald concludes that these "modern dominant ideological categories...force and subordinate other peoples' realities into our Europhone classificatory demands" (60). To that end, drawing on his knowledge and experiences as a religious studies scholar specializing in India and Japan, Fitzgerald stresses throughout his analysis the impossibility of translating categories invented in the English language into categories found in non-English (especially non-European) languages and gives several examples.

Fourth, Fitzgerald underlines that inventing and employing categories like religion and politics is not a neutral and innocent act because specifying categories sustains, and is sustained by, an intricate web of power relations. He argues that the discourse on religion

\footnotetext{
21 References to RPIR are included in the text in parentheses.
} 
based on this binary has "disguised aspects of secular power, the conceit of natural reason and its presumed grip on so-called 'reality', [and] legitimated new hierarchies of privilege and wealth" (72). Categories have to do with power, Fitzgerald insists. For instance, the 'religious' category of Sinhalese Buddhism "is inevitably involved in power relations, for example[,] in who can and who cannot join the Sangha [the community], in caste and gender issues, in internal disciplinary matters... [and] in accumulation of land and wealth" (58).

Fitzgerald demonstrates the inherent relationship between categories and power with another interesting example from Japan. He states that "in Japan the Emperor was ikigami (usually translated as 'living god') at a time when the Meiji Constitution of 1889 constituted State Shinto as the Japanese equivalent of the secular state" (50). However, "in 1946 the US occupation forces rewrote the Constitution which declared that State Shinto is really a religion and should be classified as such" and that "the Emperor is no longer ikigami but something more like a British constitutional monarch" (50). For Fitzgerald, "it is clear that power decides what gets classified as a religion and what as a secular one" (50).

Along this line of argument, throughout his study Fitzgerald engages in a critical deconstruction of several works of international relations, including Eli Berman's Radical, Religious, and Violent: The New Economics of Terrorism, Pavlos Hatzopoulos and Fabio Petito's edited volume Religion in International Relations: The Return from Exile, Scott M. Thomas' The Global Resurgence of Religion and the Transformation of International Relations, and Elizabeth Shakman Hurd's The Politics of Secularism in International Relations.22

Fitzgerald, in my view, makes an outstanding contribution, though extremely critical, to the scholarly study of the role and place of religion and the religious in international relations, and of their interactions with politics and the political, especially with the secular/liberal, despite the fact that he unequivocally rejects these categories. He offers penetrating critical insight on the reification of categories as neutral objective facts susceptible to empirical investigation with accompanying legitimations of hegemonic discursive practices, which in turn produce very concrete and highly insidious consequences. Although Fitzgerald does not allude in any way to this in his study, a strong case can be derived from its critical deconstruction for a reflexive employment of concepts in scholarly analyses through being conscious of the discursive origins of concepts, the constructed nature of dichotomies, linguistic diversity and idiosyncrasy, and the power relations involved in the scholarly practice of inventing and employing seemingly natural categories.

However, displaying the same weakness common to virtually all post-positivist approaches, especially post-modernism and post-structuralism, Fitzgerald makes no suggestions on how to study the relationship between practices that, for him, are misguidedly categorized and reified as religious, and practices, that are similarly categorized and reified as political or economic or social. Understandably, this silence is the corollary of an anti-foundational ontological position. However, research is not just about analysis; it is equally composed of synthesis. Although post-positivist approaches engage in and produce critical analysis, they are prone to stop halfway through the research and elide engaging in and producing critical

22 Eli Berman, Radical, Religious and Violent: The New Economics of Terrorism (Cambridge, Mass: MIT Press, 2009), Pavlos Hatzopoulos and Fabio Petito, eds., Religion in International Relations: The Return from Exile (New York: Palgrave Macmillan, 2003); Scott M. Thomas, The Global Resurgence of Religion and the Transformation of International Relations (New York: Palgrave Macmillan, 2005); Elizabeth Shakman Hurd, The Politics of Secularism in International Relations (New Jersey: Princeton University 
synthesis. Fitzgerald would argue that the analysis-synthesis dichotomy is just another reified and naturalized category in Anglophone academia with no factual referents, and his objection would be consistent with his anti-foundational ontological position.

Nonetheless, acts that are or are not subjected to categorization and discursive construction still exist, scholars intent on studying them still exist, and the need for scholars who not only engage in critical analyses but also aim at reaching critical syntheses still exist. Fitzgerald's evasion on suggesting ways to study the acts (the categories of which he critically and cogently deconstructs), other than a total abandonment of categories and dichotomies and holding to the "faith that, if and as critical discourse gains a footing, a democratic consensus on the language we should use to construct our collective world will emerge from the parameters of a widening public debate" (98), leaves the interested reader with no guide for where to go from here (especially if $\mathrm{s} /$ he does not endorse an anti-foundational ontological position in research) except for continuing to employ the same categories but now in a reflexive manner.

\section{Conclusion}

A specter is haunting the world - the specter of the God. After constituting the ideational foundations of international orders in the history of the mankind, then incrementally relinquishing their privileged positions in construing and shaping national and international affairs for the good and for the bad, and becoming 'privatized' in national and international public spheres, religion and the religious in the forms of agenda-setting convictions, restless actors, progressive practices, and vibrant institutions have become ubiquitous in international relations. They have proven, again, for the good and for the bad, capable of engaging other actors and shaping political, economic, and social developments, thus transforming the world in many ways at many levels. To reiterate, the major issues of contemporary international affairs cannot be exhaustively debated, the major developments cannot be thoroughly understood, and the major problems cannot be satisfactorily settled without including religion and the religious in the study of international relations, and without incorporating religion and the religious into the practice of international relations. ${ }^{23}$

It is imperative to keep in mind that international affairs is not international politics, that contemporary international politics is secular in essence, and that its secularism is predominantly defined by the ideology of liberalism. Therefore, the growing visibility and influence of religion and the religious in international relations is contrary to a foundational character of international politics, and the endeavor of religion and the religious to find and secure a credible role and place in international relations is certain to cause a troubled engagement and an uneasy renegotiation with secular politics and the secular political, especially with liberalism and the liberal. In conclusion, it seems time for scholars of international relations, who have long neglected the relevancy of religion to the discipline and quite purposefully eschewed studying its role and place in international relations both historically and contemporarily, to redeem themselves and bring religion back in, academically speaking.

23 With specific reference to the implications of bringing religion back in for theorizing in international relations see Jack Snyder, ed., Religion and International Relations Theory (New York: Columbia University Press, 2011). 